\title{
Margaret McCartney: Christmas presents
}

\author{
Margaret McCartney general practitioner, Glasgow
}

With Christmas come the presents, but since graduation they've caused me disquiet. They arrived, carefully and thoughtfully wrapped, some with notes and cards, some with just my name. In accepting gifts from patients, I was disturbed.

I thought, firstly, that they were being given under false pretences. I wasn't doing any more than the average doctor, maybe less: I'd made mistakes; had missed things that the "retrospectroscope" made obvious; and had often been less sensitive or cheerful than I should've been. I didn't deserve them, clearly.

Secondly, it wasn't right to give me chocolates or alcohol when money was tight. This wasn't a fair use of funds.

And, lastly, did accepting a gift mean that I'd entered some kind of Faustian pact? Was I going to be asked to do things that I shouldn't—for example, to make an unnecessary referral?

My medical defence union makes clear that doctors "should carefully consider the size of any gift, the patient's possible motive and any possible impact on their professional judgement." "Even if the gifts were boxes of chocolates or homemade biscuits rather than cars, houses, or cheques, I was only right to be suspicious. So I wrote polite thank you notes, feeling uneasy, afraid to feel gratitude.

This has all changed. A few years ago I was ill. When I was better, I went to buy presents for the people who had looked after me. The process of choosing, wrapping, and giving small presents felt like a natural and human response. I was grateful, appreciative, and thankful. My care had been kind and generous, populated by people who gave of themselves. By giving a gift I was responding as a person to a person, not just as a patient to a professional. I felt liberated in sending thank you cards, at expressing gladness. It made me happy to send small presents to say thank you.
I still don't think that I'm especially deserving of presents of chocolate or alcohol at Christmas. I wouldn't accept large, expensive, or monetary presents. But giving small gifts is part of our social culture. And receiving presents well is a form of gratitude in itself, an acknowledgment of the luck we have in doing this work, of being a little part of other people's lives.

Sure, we should feel suspicion about showy gifts or ones with romantic undertones. But the real point of presents is that we, patients and doctors, can together try to find the best way forward and make room for each other's human foibles.

Competing interests: I have read and understood BMJ policy on declaration of interests and declare the following interests: I'm an NHS GP partner, with income partly dependent on Quality and Outcomes Framework points. I've written two books and earn from broadcast and written freelance journalism. I'm an unpaid patron of Healthwatch. I make a monthly donation to Keep Our NHS Public. I'm a member of Medact. I'm occasionally paid for time, travel, and accommodation to give talks or have locum fees paid to allow me to give talks but never for any drug or public relations company. I was elected to the national council of the Royal College of General Practitioners in 2013 and am chair of its standing group on overdiagnosis. I have invested a small amount of money in a social enterprise, Who Made Your Pants?

Provenance and peer review: Commissioned; not externally peer reviewed.

Follow Margaret on Twitter, @mgtmccartney

Medical and Dental Defence Union of Scotland. Doctors should extend "sunshine rule" to patient gifts (press release). 15 Sep 2015. www.mddus.com/media-centre/pressreleases/2015/september/doctors-should-extend-sunshine-rule-to-patient-gifts/.

Cite this as: BMJ 2015;351:h6655

๑ B BMJ Publishing Group Ltd 2015 